\author{
Historical Studies in Education / Revue d'histoire de l'éducation \\ ARTICLES / ARTICLES
}

\title{
"Teachers Amongst their own People": Kanyen'kehá:ka (Mohawk) Women Teachers in Nineteenth-Century Tyendinaga and Grand River, Ontario
}

\author{
Alison Norman \\ Ontario Ministry of Indigenous Relations and Reconciliation* \\ and Frost Centre for Canadian Studies \& Indigenous Studies, Trent University
}

\begin{abstract}
In the mid-nineteenth century, the New England Company (NEC), an Anglican missionary society, focused many of its efforts on hiring Indigenous teachers for its schools at Grand River and Tyendinaga, two Haudenosaunee (Iroquois) communities in southern Ontario. The NEC believed that it was useful to hire Indigenous teachers due to their ability to speak to the students in one of the local Indigenous languages as well as in English. Many Haudenosaunee leaders and families also believed that a Western education would benefit their children and therefore supported the construction of churches and schools. Kanyen'kehá:ka (Mohawk) women born into this cultural environment worked to build careers for themselves as on-reserve educators. Some struggled to secure meaningful employment due to their gender, while others found work but faced numerous challenges in performing their jobs. This paper reveals that Kanyen'kehá:ka women persisted as teachers despite gender and material barriers, creating models for participation in colonial education for Haudenosaunee youth in the nineteenth century.
\end{abstract}

RÉSUMÉ

Au milieu du XIX siècle, la New England Company (NEC), une société missionnaire anglicane, a consacré beaucoup d'efforts afin d'embaucher des enseignants autochtones pour ses écoles de Grand River et de Tyendinaga, deux communautés Haudenosaunee du sud de l'Ontario. La NEC croyait qu'il était utile d'embaucher des enseignants autochtones en raison de leur capacité à parler aux élèves dans l'une des langues autochtones locales, aussi bien qu'en anglais. Plusieurs dirigeants et familles Haudenosaunee soutenaient également la construction d'églises et d'écoles, parce qu'ils croyaient qu'une éducation occidentale profiterait à leurs enfants. Les femmes Kanyen'kehá:ka (Mohawk) nées dans cet environnement culturel ont travaillé à se bâtir des carrières comme éducatrices sur les réserves. À cause de leur genre, certaines ont dû lutter afin d'obtenir un travail significatif, alors que d'autres ayant trouvé un emploi ont dû affronter de nombreux défis dans l'accomplissement de leur travail. Cet article révèle que malgré les difficultés matérielles et la barrière du genre, les femmes Kanyen'kehá:ka ont persistées dans le domaine de l'enseignement, créant ainsi des modèles de participation à l'éducation coloniale pour la jeunesse Haudenosaunee au XIX ${ }^{e}$ siècle. 
The important and varied roles that Haudenosaunee (Iroquois) women played in their communities in the past has been well documented by anthropologists and historians, and the role that they played in educating the children of the community prior to contact and the arrival of Western education is also well-known. Kanyen'kehá:ka (Mohawk) ${ }^{1}$ historian Keith Jamieson has written that women were central to the education of Haudenosaunee children. He notes that mothers, as well as all of the women of the Longhouse, "shared in the task of developing in the child, an appreciation for the home and family, language, values and beliefs." Women were responsible for caring for children in the village community, especially when men were away hunting, trading, and engaging in diplomacy and sometimes war. Children were cared for and taught by women until boys were old enough to be taught gender-specific skills (and girls stayed with the women to learn from them). ${ }^{3}$ What is less well-known or understood is the role that Haudenosaunee women, and Kanyen'kehá:ka women specifically, played in the missionary-run day schools located on reserves in southern Ontario in the nineteenth century. Both Haudenosaunee men and women played important roles in the education of their young, but women in particular were significant participants in the new education system. Their reasons for working in these schools likely varied, and, their desire to teach, at different times and places, was supported or denied by Haudenosaunee chiefs, the colonial and Dominion governments, and church officials. Kanyen'kehá:ka women faced numerous challenges, both in becoming employed and once they were working as teachers. The multiple barriers that may have had an impact on their ability to perform as onreserve educators included poorly-funded schools, substandard facilities, and unequal pay, as well as a lack of respect from missionaries and government officials.

This paper focuses on four Kanyen'kehá:ka women who worked (or attempted to work) in local day schools on the Six Nations of Grand River Reserve, and on the Tyendinaga Mohawk Territory (Kenhtè:ke) in the second half of the nineteenth century. Catherine Loft Claus was likely the first Kanyen'kehá:ka woman certified to teach in Ontario, and possibly the first Indigenous woman certified to teach in Canada. Her three cousins, Lydia Hill, Elizabeth Martin Powless, and Jemima Loft Beaver, all began teaching at schools in the 1860s and 1870s in the two reserve communities. These four women, tied by blood and marriage, were descended from many of the important leaders of the communities in both Tyendinaga and Grand River. Despite the challenges that they faced because they were women teachers, their efforts and careers teaching in missionary-run schools continued the Haudenosaunee tradition of female educators and provided an important cultural link for Haudenosaunee children in local day schools.

One reason we know relatively little about these women is that the records for these schools are not centralized like the records of residential schools. ${ }^{4}$ And while several scholars have published their research on day schools, we know very little about the Indigenous teachers who worked in them. ${ }^{5}$ This paper contributes to the process of uncovering teachers' life stories by taking a microbiographical approach. American historian Ronald Hoffman suggests that historians working from a biographical perspective "endeavour to discern through the lives of individuals or families the broader 
contours of the social and cultural landscape." By looking at the lives of Claus, Hill, Powless, and Beaver, the complexities of their communities and their culture in the late nineteenth century becomes apparent. Too often in Indigenous history, individuals are left out of the story in favour of generalizations about the community. Social science methods often ignore the specifics of individual lives or use case studies of anonymous subjects. Haudenosaunee communities were (and, indeed, are) complicated places where people had diverse ethnic and national backgrounds, religions, and political perspectives. It is only by examining the lives of specific individuals in some detail that it is possible to gain a better understanding of the educators working in the colonial system. While these women left very few records of their own and are only briefly mentioned in missionary, government, and public records, it is possible to "read beyond words" in order to paint a picture of how their careers were affected by their gender and the material barriers they faced working in on-reserve day schools. ${ }^{7}$

\section{Christianity, Schools, and Haudenosaunee Lands}

The Kanyen'kehá:ka are one of the Six Nations of the Haudenosaunee Confederacy, originally located in upstate New York. Each of the Six Nations-Kanyen'kehá:ka (Mohawk), Onoñda'gega' (Onondaga), Onötowà'ka (Seneca), Onyota'a:ka (Oneida), Gayogo hó:no' (Cayuga), and Ska:rù:rę' (Tuscarora) — had their own lands, political leadership, and languages that belong to the same language family. At the close of the American Revolution in 1783, thousands of Loyalist Haudenosaunee people migrated from New York to Quebec (to the region that became Upper Canada) where they were granted tracts of land in return for their loyalty to the British Crown. Two thousand Haudenosaunee people from varying nations settled along the Grand River in the Haldimand Tract in what is now southwestern Ontario, and a smaller group of mostly Kanyen'kehá:ka people settled at Tyendinaga, near Deseronto, in what is now eastern Ontario. ${ }^{8}$ The residents of these two communities, separated by about three hundred kilometres, were often related by blood and marriage. Movement between the two communities was common.

In 1784, after the American Revolution, the Kanyen'kehá:ka leader Joseph Brant (Thayendanega) led about two thousand Haudenosaunee from multiple nations to Grand River, north of Lake Erie. A smaller contingent of Kanyen'kehá:ka followed war chief John Deserontyon (Odeserundiye) to the eastern end of Lake Ontario, on the Bay of Quinte, in the same year. Records suggest there were about twenty families, totaling about 120 people, with several chiefs and captains acting as leaders. ${ }^{9}$ Sir Frederick Haldimand, governor of the province, had promised that the new settlement at Grand River would have a sawmill, grist mill, a church, and a school, and that funding was to be provided for the schoolteacher's salary $-£ 25 .{ }^{10}$ People worked to clear land for agriculture, to build homes, and to erect schools and churches in both communities. These were generally not new Western colonial structures since the communities they left behind in New York also had many of these institutions and buildings. ${ }^{11}$

Anglicanism was a prominent faith among the Kanyen'kehá:ka at the Bay of Quinte, and they began to build St. George's Anglican Church on the territory 
within five years of their arrival, completing it in 1794. A new stone church replaced the initial wooden structure in $1843 .{ }^{12}$ Other Christian churches were also built, including a Catholic church in Marysville in 1831 and more Anglican churches at Shannonville: Holy Trinity in 1854 and All Saints in 1858.

Not only was the Christian faith important to many of the Kanyen'kehá:ka, but so too was Western education. The first day school was established almost immediately in 1784 when the New England Company (who had worked with the Kanyen'kehá:ka at Fort Hunter in New York) built a school. The chiefs were to choose the teacher, and that person was to be paid by the British. ${ }^{13}$ Major John Norton (Teyoninhohovrawen), an ex-soldier of Scottish-Cherokee descent who later became an adopted nephew to Joseph Brant, worked there as a teacher. ${ }^{14}$ The school used a primer published in London in 1786 that had been written by Daniel Claus, the former commissioner of Indian Affairs who had recently been appointed deputy agent of the Six Nations. He oversaw the settlement of Haudenosaunee people at both Tyendinaga and Grand River, was well-known to the people, and spoke some of their dialects. ${ }^{15}$ The primer was printed in both Kanyen'kehá and English, with lessons in the two languages on facing pages so that students could "acquire the spelling and reading of their own, as well as to get acquainted with the English, language." 16 The image in Figure 1, from the frontispiece of Claus' primer, shows a male teacher surrounded by children in a Western-style wood-frame building using the primers or other books to learn their lessons. Elizabeth Elbourne's recent work on Anglicanism and the Haudenosaunee in northeastern North America suggests that these sorts of resources, produced by missionaries and military officials, were in demand by Haudenosaunee people, who saw the faith as a way to strengthen the bond and alliance between the British and the Haudenosaunee, and particularly the Kanyen'kehá:ka. ${ }^{17}$ The demand for Western education grew at Tyendinaga, and two more schools were built by the 1860s; Christianity, and Christian schooling, was important to the growing community.

Anglicanism was also strong at the Six Nations of Grand River, where early leaders, including Joseph Brant, encouraged conversion to Christianity. Brant requested the construction of a church, and as a result, the first Anglican church built in Upper Canada was the Mohawk Chapel on the Grand River Reserve, built in 1786, just after the Six Nations arrived from New York. ${ }^{18}$ Through the nineteenth century, several other Anglican churches were constructed, and some were moved after the consolidation of the reserve in 1847. St. John's was the second church. Built in 1829, it was originally located in the Ska:rù:rę' (Tuscarora) Village and later moved to the consolidated reserve in 1884. St. Paul's, also known as Kanyengeh, was built in 1865 in the West Parish. Christ Church, also known as Cayuga, was built in the East Parish in 1874 and St. Luke's Delaware Church was built in $1888 .{ }^{19}$ By the 1890 s, the Anglicans made up about half the Christian people at Grand River, with Baptists and Methodists making up the rest of the Christian population. ${ }^{20}$ The churches were closely connected to the schools and funded in part by the missionary societies who hoped to convert adherents from the Longhouse faith, the traditional religion of many Haudenosaunee people after about $1800 .{ }^{21}$ 


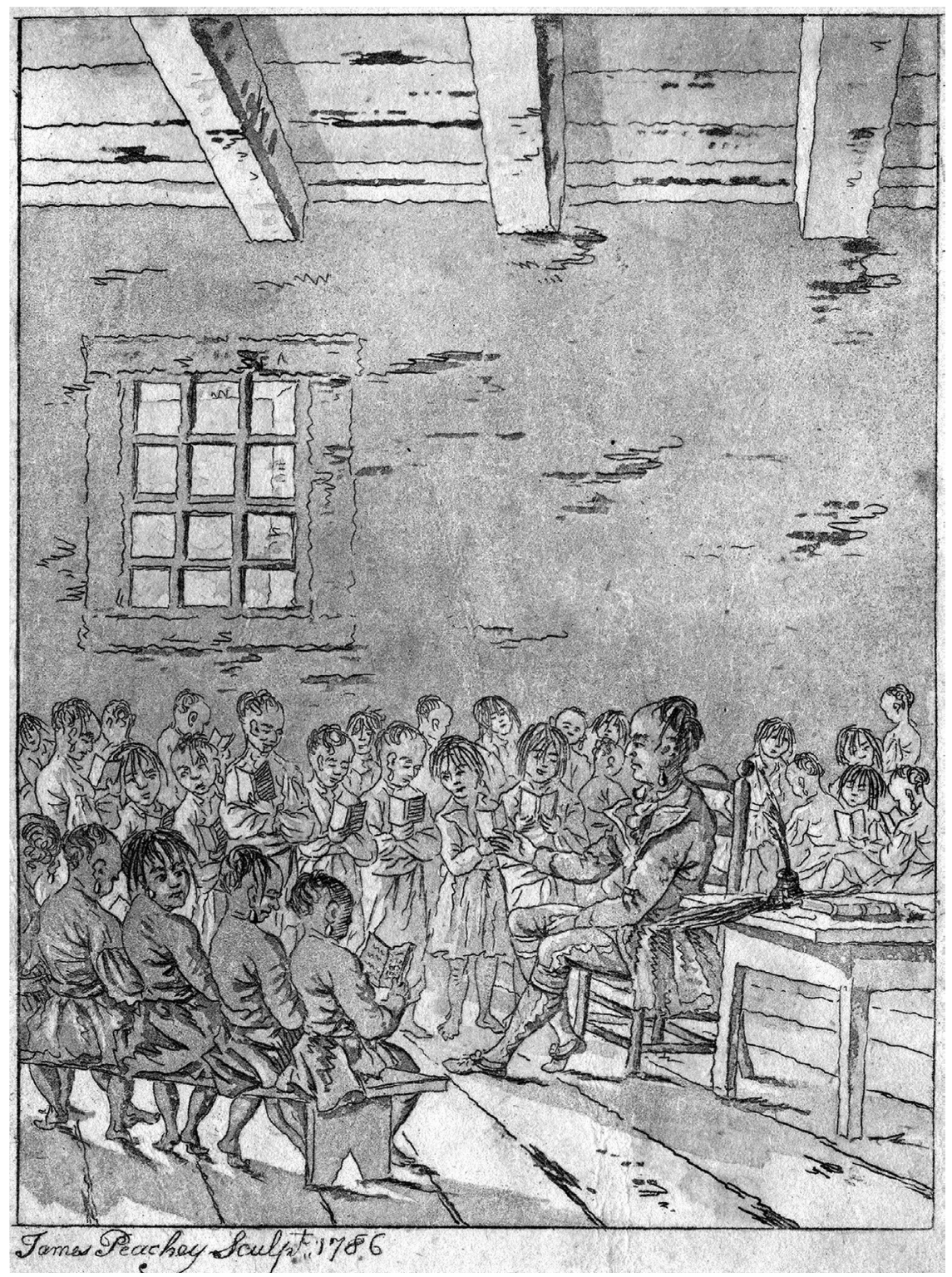

Figure 1: The frontispiece of A Primer for the Use of the Mohawk Children/Waerighwaghsawe Iksaongoenwa. London, England: C. Buckton, 1786. Photo courtesy of Western Archives, Western University, London, Canada.

Initially, consistent funding was a challenge, and yet the number of schools and churches grew. At Grand River, the first school was built in 1786 at the Mohawk Village, and Kanyen'kehá:ka teachers also used Kanyen'kehá prayer books and primers to teach the children. But the British failed to deliver on the promised funding, 
and so some of the schools were short-lived. A school was built in the Ska:rù:rę' (Tuscarora) Village in 1819 and attendance waned. ${ }^{22}$ In an effort to acquire permanent support for schools in their communities, John Brant, Joseph's youngest son, travelled to England in 1822 to meet with the New England Company, a Protestant missionary society, and asked them to provide for a teacher, "preferably an Indian competent to teach 'plain reading and writing,' "' to the Kanyen'kehá:ka community at Grand River. ${ }^{23}$ Brant was successful in his mission to acquire some financial stability; the NEC gave him $£ 200$ for the school, of which $£ 25$ was earmarked for the teacher's salary. Over the next decade, the Company contributed several hundred more pounds towards the construction of schools and the appointment of missionaries and teachers in their Canadian mission field — at Grand River and Tyendinaga as well as near Peterborough and Garden River.

Funding for Indigenous schools was a priority for the NEC and, as the numbers of Christians grew during the nineteenth century, their efforts had some support within the communities. In response to demand, additional schools were built along the Grand River during the 1830s in the individual communities of the Onyota'a:ka (Oneida), then the Ska:rù:rę' (Tuscarora), and then the Gayogohó:no' (Cayuga). ${ }^{24}$ In 1834, one of the day schools that had been founded several years earlier in the Kanyen'kehá:ka Village by NEC missionary Robert Lugger became a boarding school for boys and girls, first called the Mohawk Institution, and later known as the "mush hole" for the food that was served there. ${ }^{25}$ It later became an important site for educating and training Haudenosaunee teachers. Throughout the nineteenth century, and especially after the consolidation of the reserve in 1847, more new day schools were built, so that by 1900 , there were twelve day schools on the Grand River Reserve and four day schools at Tyendinaga.

It is clear from this expansion in the number of schools that these Haudenosaunee communities valued at least some aspects of Western education. The building programs at Tyendinaga and Grand River are evidence not only of attempts by government and church officials to "civilize" and Christianize Haudenosaunee people, but also of a demand for these Western institutions by Haudenosaunee leadership, who were supportive of the initiatives for their own purposes.

\section{Hiring Indigenous Teachers}

From quite early on, some missionaries and NEC staff realized that it would be more economical and practical to hire educated Indigenous teachers from within the communities themselves. This thinking was not a result of colonial officials believing that it would benefit the children to have an Indigenous teacher, but rather because they believed it would make the "civilization" process more efficient. ${ }^{26}$ In fact, the NEC had relied on the same tactic, training local Indigenous people to work as teachers in schools for Indigenous children, in colonial New England in the midseventeenth century. ${ }^{27}$ Indigenous teachers and missionaries were also hired by the organization in eighteenth-century New York, where Paulus Sahonwagy, an Anglican Kanyen'kehá:ka teacher and missionary taught children and led prayer services for 
adults in Canojoharie for decades in the mid- to late-eighteenth century. ${ }^{28}$

At Grand River, as the number of schools expanded, NEC officials discussed the merits of hiring Indigenous teachers. In 1837, lay agent William Richardson toured the Mohawk Institution (later the Mohawk Institute), and Hannah Nelles, the Rev. Abram Nelles's wife, advised him that some of the girls at the school "might become very useful in the education of children in their respective neighbourhoods." She advocated that they be exempted from "menial duties" at the school to have time to study. Her husband and the NEC agreed. ${ }^{29}$ In a report a few years later, the Company argued, "it is very desirous of completing the education of at least a few [girls], that they may be qualified to instruct the younger children." ${ }^{30}$ In the early 1840s, Lawrence Davids, a Kanyen'kehá:ka man, was teaching at a school in the Delaware settlement on the reserve, and the NEC believed he was a more successful teacher than a white teacher would have been. ${ }^{31}$ While the NEC did not keep consistent records of the schools they funded, annual reports from the mid-nineteenth century show that officials were willing, and at times even keen, to hire local Indigenous people. For example, Nelles reported the following:

It is satisfactory to observe an increasing desire on the part of the Indians to have their children educated... This improved state of feeling among the Indians is probably chiefly brought about by the influence of those who have been educated at the Company's schools, of whom four are now engaged as School Teachers, five as Catechists, besides many others who render much useful assistance both to Mr. Eliot and myself, by their advice and example. ${ }^{32}$

It is possible that Indigenous teachers encouraged a more positive feeling in the general population towards schooling, and they were likely more efficient in their teaching because they were able to communicate with their students in their own languages.

Language was an important issue for on-reserve day schools. In an 1842 government report on "The Past and Present Condition of the Six Nations," local missionaries reported "the mode of teaching is the same as that among Common Schools for the Whites, and the Books in use are those recommended by the Board of Education... the Instruction is carried on altogether in English." 33 While missionary and government policy in the mid-nineteenth century was for schoolchildren to be learning in English, there is some evidence to suggest that community members wanted children to learn their own languages, and that some teachers did in fact teach in Kanyen'kehá and other Haudenosaunee languages. In 1843, for instance, Kanyen'kehá:ka leaders from the Bay of Quinte requested that children be able to attend a school where they would learn in Kanyen'kehá and in English. They also offered to pay for the cost of more primers and other books in Kanyen'kehá, but the superintendent of Indian Affairs at the time, T. G. Anderson, argued that "the intercourse of the rising generation must be with whites and it therefore appears to me that teaching them in their own language is time and labour lost." ${ }^{34}$ Clearly community members valued their own language and saw a place for it in the Western education system, even if officials did not. 
Despite the policies of the missionary society and Indian Affairs, there is good evidence that Indigenous teachers used their own languages to teach children the curriculum. For example, in 1870, the NEC reported that " $\mathrm{i}] \mathrm{t}$ has been for some time past thought most advantageous to employ Indian teachers, on account of their ability to explain to the Indian children their English lessons in their own language." 35 A more detailed report by an NEC official who toured all of the churches and schools that same year further explained the benefit of teaching in Haudenosaunee languages:

The following school-teachers, paid by the Company, are capable of conversing with their pupils in their own dialects, Isaac Barefoot, Alexander Smith, Mrs. Powless, Daniel Simons, Mrs. Beaver, Isaiah Joseph, and James Hill [all Haudenosaunee teachers]. No doubt it is in some respects an advantage for the teacher to be able to explain to the children, when first sent to school, in their own language, what is being taught to them; still, as one of the first and most essential things to be taught the Indian pupils is to speak English, and in a manner to forget their own tongue, it is by no means absolutely necessary that the teacher should possess a knowledge of the dialects of the Six Nations Indians. ${ }^{36}$

Clearly, NEC officials were not interested in Haudenosaunee children maintaining fluency in their own languages, but having Haudenosaunee teachers using their languages in school was important. Another report makes it clear that children were bilingual, and conceded that, with "Indian masters," "pupils evidently understood what they were learning, so as to be able to give an intelligent account in their own language of the lesson that they were reading or learning in English." ${ }^{37}$ Children at these schools were learning to read and write in both English and Haudenosaunee languages. Evidence suggests that a shift had occurred, and missionaries accepted that, if they wanted children to learn, allowing teachers to teach in their own language or the language of the children was necessary.

\section{The Mohawk Institute}

At the same time that Kanyen'kehá:ka teachers were teaching at least in part in their own language, the local residential school at Grand River, the Mohawk Institute, became an important locale for the education and training of Indigenous teachers. In 1859, they employed four graduates as staff. ${ }^{38}$ By the 1870 s, it became the Institute's stated aim: "to impart such an education as shall fit its pupils for teachers amongst their own people, at the same time training them in the arts and practices of civilized nations." ${ }^{39}$ The school played a central role as a teacher's college in the nineteenth and into the early twentieth centuries, so much so that in 1885 it was nicknamed the "Indian Normal School." ${ }^{40}$ The missionaries and officials at the school realized that the most promising students should have the opportunity for further education and training for a variety of careers, but teaching seems to have been the most popular 
choice. By the 1890s, the Mohawk Institute had graduated twenty-five girls and twenty boys who went on to become schoolteachers in reserve day schools and other residential schools. ${ }^{41}$

From about the 1870s onwards, almost every year the Institute requested funds from the NEC for a select number of students to further their education at various colleges in southern Ontario, including Huron College, Hellmuth College, and the Toronto Normal School. Interestingly, Rev. James Chance, in writing to the NEC about funding for a young man to be sent to the Normal School, explained that

It would be very unadvisable to send one Indian youth alone as he would be subject to that overwhelming sense of loneliness which Indians are so liable to experience when separated from their people and which would operate against his remaining there or seriously interfere with his peace and progress and four trained teachers would be of great service in the schools on the Reserve. ${ }^{42}$

Likely there had been some previous candidates who had suffered from loneliness and possibly failure, while attending these schools far away from home, in foreign cities, surrounded by a mostly (if not entirely) non-Indigenous student body. A group of three or four teacher candidates in the city of Toronto would have lived in a more supportive environment than a student attending alone. ${ }^{43}$

Isaac Barefoot, an Onondaga man, was perhaps the best known among these teachers. A graduate of the Mohawk Institute, he taught in a local day school, went to Huron College, and then was the first Indigenous person to teach at the Mohawk Institute, where he remained for many years. He later became the school inspector at Six Nations and an ordained minister in the Anglican church. ${ }^{44}$ Not all of the Indigenous (or non-Indigenous) teachers who taught in reserve day schools, however, attended a school like Huron College or the Toronto Normal School before they began teaching, and the path to a career was not always straight or easy.

\section{Career Aspirations of Haudenosaunee Women: Catherine Loft}

While Haudenosaunee women had traditionally educated their communities' youth, women struggled to build careers for themselves as day school educators in on-reserve day schools. In 1860, a twenty-year-old Kanyen'kehá:ka woman named Catherine Loft took it upon herself to train as a teacher. Shortly thereafter, the Hastings County Board of Public Instruction granted Loft a teacher's certificate. Loft grew up on a farm on the Mohawk reserve known first as the Mohawk of Bay of Quinte and later as Tyendinaga, with her parents and her younger siblings. She was most likely educated in one of the reserve missionary day schools, where the vast majority of children were educated. It is unclear from the archival record where she trained, but the fact that she undertook such training in order to be hired to teach is somewhat extraordinary. She must have been an intelligent, capable, and proactive woman. And yet she was not hired by the Kanyen'kehá:ka councilors to teach in one of the local schools because she was a woman, despite the fact that she had the backing of 
the local missionary and the superintendent of the Department of Indian Affairs. ${ }^{45}$

Catherine was born at Tyendinaga in 1837 to John Loft, Junior and Catherine Crowe. She was a great-granddaughter of Captain Isaac Hill (Anonsoktea), a wellknown Kanyen'kehá:ka warrior who fought alongside Captain John Deserontyon (Odeserundiye) in the American Revolution, and who came to Tyendinaga after initially settling at Grand River; he left after having a dispute with Joseph Brant. ${ }^{46}$ Isaac Hill's wife was Lydia John, Deserontyon's sister. ${ }^{47}$ By 1859 , eighteen-yearold Catherine came to the attention of Visiting Superintendent of Indian Affairs William Bartlett as she was "endeavouring to qualify herself for a school teacher, and that she intended going before the Board of Examiners, with the view of obtaining a certificate, when she hoped to be appointed to the Indian School." ${ }^{8}$ The superintendent viewed this as "proper and desirable" and noted that he was very supportive of having Kanyen'kehá:ka teachers working in Kanyen'kehá:ka schools. The following year, he wrote to the councilors, the hereditary chiefs at Tyendinaga, saying that he had been informed that Catherine had been granted a certificate from the County Board of Public Instruction, and that "this is highly creditable to her, and it ought to be gratifying to you to find one of your own band thus taking advantage of the means of education provided by [to] the Mohawks and by perseverance and study to qualify herself for a school teacher." ${ }^{49} \mathrm{He}$ proposed that she be hired for three months on a trial basis and, if she proved satisfactory, then the council could decide on her salary. There were three school trustees at the time, including Rev. G. A. Anderson, the NEC missionary, and two Kanyen'kehá:ka chiefs, Seth W. Hill and Nelson Martin. Catherine had the support of Missionary Anderson who wrote that, after all her work to qualify herself as a teacher and become certified, if she was not given a chance to teach, "it may deter others [Haudenosaunee women] from trying to improve their education." 50

Despite the support of the superintendent and missionary, the two Kanyen'kehá:ka school trustees would not approve the proposal to hire Catherine on a trial basis. They gathered their supporters and threatened that if she were hired, they would make their children turn her out of the school. These same councilors had previously been critical of the white, male, and non-certified teacher, Mr. Glenholm Garrett, but suddenly began to support him. ${ }^{51}$ In a February 1860 letter, Bartlett noted that a previous councilor had lent Garrett $\$ 80$ "from the Indian Trust" and promised him $\$ 240$ a year for two years as teacher in order to enable him to repay the borrowed money. ${ }^{52}$ This may explain, in part, why the councilors wanted to keep Garrett employed at the expense of Catherine Loft. Or it may be that the strained relations between Indian Affairs and the councilors resulted in a refusal to hire Loft because she was being supported by colonial officials and the missionary.

At the councilors' refusal to hire Loft, Missionary Anderson was in despair, and wrote to Bartlett "these Mohawks are really an unmanageable band and make me sick of my post." ${ }^{33}$ When the issue came before the council in the summer of 1860 , the councilors "strenuously" objected to hiring Catherine Loft (or "any female") for two reasons. According to Bartlett: "the first that it was as much as a man could do 
to manage and control unruly boys, and second, that her English pronunciation was imperfect. These were certainly very strong reasons. With a view of ascertaining the feeling of the whole band on the subject, I submitted the question to the Council, where by a large majority it was decided not to employ a female teacher." ${ }^{4}$ Even if she had been hired, Catherine's father was apparently afraid to send her to the school because community members had threatened her. ${ }^{55}$ Why exactly the councilors refused to hire Catherine remains unclear. The archival record is silent about the reasons why the councilors stuck to their decision, and a recent community profile of Catherine Loft does not explain this turn of events. ${ }^{56}$

Five years after these events, in 1865, Catherine Loft married and subsequently gave birth to seven children. But whether she ever used her teaching skills beyond her own family is unknown. We can speculate that she felt a calling to become a teacher, and that she wanted to carry on the tradition that Haudenosaunee women played in educating the young and passing on their history, culture, language, and traditions, but of course, we cannot know. We can imagine that she was likely disappointed at her own stalled career. Loft's story reveals the challenges that women faced finding employment as teachers.

\section{Material Barriers to Effective Teaching: Jemima Loft Beaver}

Kanyen'kehá:ka women who successfully became teachers in reserve day schools faced multiple barriers that may have had an impact on their ability to perform. These include inconsistent and poor funding and unequal pay. Jemima Beaver, a Kanyen'kehá:ka woman and Catherine Loft's first cousin once removed, was likely the first Indigenous woman to teach on the Grand River Reserve. ${ }^{57}$ Her life reveals to us the ways in which some of these teachers worked within missionary cultures of education and schooling, despite limited access to the resources necessary for effective teaching.

Jemima Beaver was born in 1833 at Tyendinaga. In the early 1850s, Jemima and her siblings, Susannah (or Sa-sa-na) and George, took up work as travelling performers and Christian gospel singers. They traveled around southern Ontario and upstate New York to raise money in order to print copies of Kanyen'kehá translations of the Bible. ${ }^{58}$ In so doing, they attracted the attention of author Susanna Moodie who commented on the family in her 1853 book, Life in the Clearings versus the Bush:

There is a Mohawk family who reside in this [Tyendinaga] township of the name Loft, who have gained some celebrity in the colony by their clever representations of the manners and customs of their tribe. They sing Indian songs, dance the war-dance, hold councils, and make grave speeches, in the characters of Indian chiefs and hunters, in an artistic manner that would gain the applause of a more fastidious audience. ${ }^{59}$

While Moodie's comments clearly display the colonial fascination with the noble savage, it is a useful description of what their performance might have looked like, 
and an example of how they were received in mid-nineteenth century Canada West. In Figure 2, we can see how the Loft siblings portrayed themselves publicly, at least for this portrait. The tintype, likely taken in the early 1850 s before Susannah's death in 1852, shows the family in Western clothing similar to what non-Indigenous people in New York or Canada West might have worn. Similar to the practice of other nineteenth-century performers, it is possible the siblings changed into more traditional Haudenosaunee clothing before they got on stage. But in this image, their clothing and poses suggest an effort to conform to Anglo-American conventions and project respectable, "civilized" womanhood and manhood.

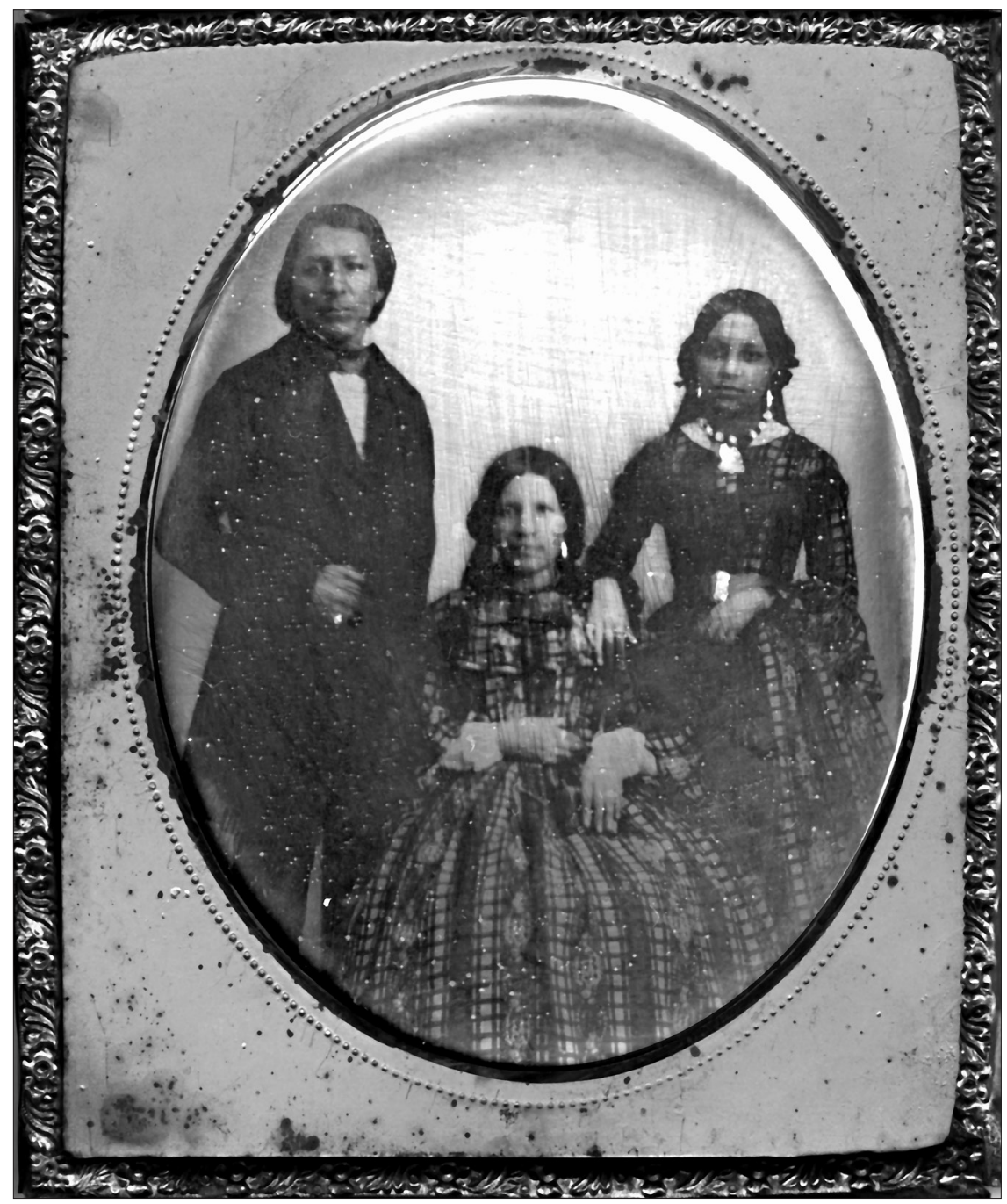

Figure 2: Tintype of the Loft siblings. Courtesy of the Rochester Museum \& Science Center. 
Jemima was relatively well-educated and intent on the education of Kanyen'kehá:ka and other Haudenosaunee people. While details of the Loft siblings' childhood are scarce, Susannah's obituary describes her apparent life purpose: "[H]er life had been spent from early youth, in an unremitted effort to acquire a knowledge of the English language and its literature, in conjunction with her brother and sisters, to diffuse civilization and the principles of our Christian faith, among the people of their nation in Canada." ${ }^{60}$ This obituary suggests that some of the Loft children attended a school thirteen kilometres from their home, and that the older children helped educate the younger. Additionally, a pastor's wife also provided "intellectual and moral training" to Susannah and her older sister (and likely one of their cousins, either Catherine or Lydia Loft). Susannah "in turn, became the principal instructress of her younger sister, Ya-go-we-a [Jemima].”61 In the years after Susannah's death, Jemima moved to Grand River, and then she married John Beaver. Jemima's educational background, her experience as a performer, and her faith as a Christian all coloured her work as a teacher, although what her students thought of her teaching, and what she thought herself, are lost to us.

What we do know, however, is that despite her active role in fundraising for Kanyen'kehá books and resources, she taught at Grand River with limited resources. The snippets of information we have from the two schools where she taught during the 1860 s and 1870s tell us about the challenges she faced. In January 1872, the missionary Rev. Robert J. Roberts noted that students at Beaver's school, No. 6, had no ink or pens and no desks, although they did have copybooks. ${ }^{62}$ The "school" was in fact an upper room in the Beaver family house, and Sunday school and other religious services were also frequently held there. Attendance was low, and as a result, Beaver's school closed and she moved to teach at No. 9 while a new one was built. Low attendance was a common problem in day schools across the province (and likely beyond) because children's parents kept them from school in order to participate in seasonal community activities, such as berry-picking.

\section{Unequal Pay and a Lack of Respect: Lydia Hill}

While many silences remain about the details of these women's lives, the historical record provides rich details about teachers' salaries. There is good evidence that women were not paid on an equal footing to men, a barrier that may have affected their ability to perform or the desire for some women to teach. While the NEC paid teachers' salaries for much of this period, Martin Benson, the Department of Indian Affairs clerk of schools, believed they could pay women less than men: "[T]he salaries paid [in day schools] are not sufficient to induce the right kind of persons to look for such employment, and most of these who seek such situations are generally unfitted for the work, either lacking in energy or qualifications. This does not, however, apply to the female teachers who are as a rule contented to receive even the small salaries offered by the Department." ${ }_{63}$ The first Kanyen'kehá:ka woman hired to teach at Tyendinaga suffered from this discriminatory attitude.

Lydia Hill was the daughter of John W. Hill and Catherine Brant. She was born 
in 1845 in Tyendinaga. She was about a decade younger than her cousin Catherine Loft, who, in 1860, the councilors refused to hire. ${ }^{64}$ Although Catherine was unable to teach school at Tyendinaga, ten years later, Lydia was more successful. In 1870, following the passage of the 1869 Gradual Enfranchisement Act, considerable political change occurred: an elected council replaced the hereditary chiefs. Among those newly-elected were Chief John Loft, Catherine's father, and Chief John Claus, her husband. The elected council began its work in October of 1870, just months after Lydia Hill was hired. It is unclear if there was any connection between her hiring and the change in government, but both men's relationships to Catharine and her cousin is suggestive of this conclusion.

Lydia Hill taught at the third school built at Tyendinaga. As was the case with many other teachers hired during this period, she spent a year at the Mohawk Institute "preparing herself for teaching," before beginning to teach at what was known as the Upper Mohawk School in $1870 .{ }^{65}$ Hill taught for several years throughout the 1870 s, but then no longer appears on the lists of teachers. She travelled through western Canada, taught Sunday school, and was the organist for All Saints Anglican Church. While she never married, she took in boarders; in 1911 the census records her as the head of a household of thirteen people. ${ }^{66}$ Her obituary noted that she made a trip to England "in the interests of education." 67

Over the course of her career, Hill was paid less than the men and non-Indigenous women working at other reserve schools during the same time period, sometimes earning less than half as much. In 1874-1875, for example, the non-Indigenous male teacher William J. Wilson was paid $\$ 370$ per year, the non-Indigenous female teacher Clara Brown made \$300, while Lydia Hill earned a mere \$150. ${ }^{68}$ The Department of Indian Affairs listed salaries and who paid them in its annual reports; the report for 1874-1875 notes that the two white teachers were paid from both "Indian" and white funds, likely because white children also attended the schools taught by white teachers, but Lydia Hill was paid from "Indian" funds only, and as a result, was paid significantly less. ${ }^{69}$ Jemima Beaver also suffered from material barriers to teaching and unequal pay. In 1864, the records show that she taught sixteen students on average at the No. 6 School for $\$ 160$ a year, which is what all of the women teachers were paid, while Isaac Bearfoot and George Moses, two Haudenosaunee men, were earning $\$ 200$ a year. $^{70}$

\section{A Lack of Respect: Elizabeth Powless}

Not only were Kanyen'kehá:ka women teachers paid less than men, they were rarely respected or valued by Indian Affairs officials or the NEC. For instance, Jemima Beaver had a long teaching career, and she is mentioned numerous times in NEC reports in the late 1860s and early 1870s, and yet not one positive statement is made about her instruction, her school, the results of her teaching, or her character. The same holds true for Elizabeth Powless, another Kanyen'kehá:ka woman teacher at Grand River in the 1860s, who was part of the first generation of Indigenous women teachers in these two Haudenosaunee communities. 


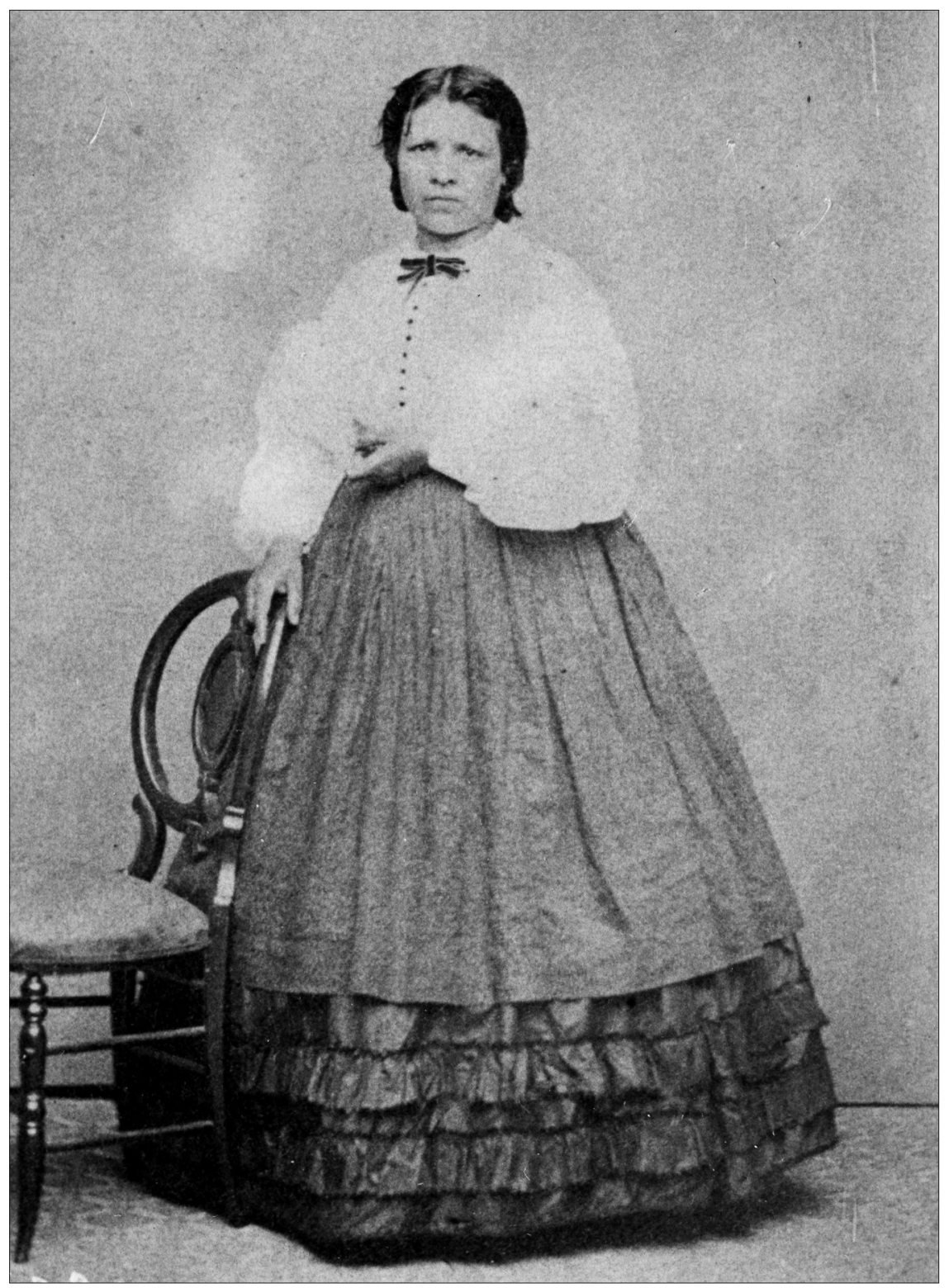

Figure 3: Portrait of Mrs. Powless, or Dayo-ra-co-sa (Sun in Water), Viroqua's sister Elizabeth, n.d. NAA INV 00783600. National Anthropological Archives, Smithsonian Institution.

Elizabeth Martin Powless was another cousin of Catherine Loft's (her first cousin). As a teacher, she was known as Mrs. Powless, but her Kanyen'kehá name was Dayora-co-sa, meaning Sun in Water. ${ }^{71}$ Powless taught at the No. 4 School around the same time that Jemima was teaching at No. 6; they were first cousins once removed. 
Elizabeth was born in 1837 at Grand River to Lydia Loft (of Tyendinaga) and Peter Martin. ${ }^{72}$ Elizabeth was married quite young to George B. Powless (a descendant of Joseph Brant) in 1850 at the Mohawk Chapel by the NEC missionary Rev. Abram Nelles, who later hired her to teach. Her son George was born in 1851, and he attended the Mohawk Institute as a child. ${ }^{73}$ Powless began teaching at some point in the early 1860s, and taught at both the No. 6 School and later at the No. 4 School. ${ }^{74}$ Like Jemima Beaver, Powless faced material barriers to teaching caused by declining attendance; there was discussion of closing the No. 4 School by about 1870 .

Many of the early schools at Grand River used log houses that were falling into disrepair by the 1870s, and the NEC wanted to replace them. The NEC often moved the school to a better location within the same area and sometimes used the move as an excuse to hire a new teacher. There is a tantalizing reference to a letter written by Powless in late 1870 to the treasurer of the NEC, and the Company wrote to the Rev. Adam Elliott to follow up on what seems to have been her request for the formation of a new school section in the vicinity of her school, and for the appointing of trustees (by the local people) to attend to the business of the school. Powless's letter no longer exists, and the NEC report only published the response from the Rev. Elliot. It seems that Powless's request, however, was an effort to push for a structure that would make her a more successful teacher. She was concerned about low attendance and her solution to the problem was both a better-defined service area for the school and greater involvement of the local community. The NEC found that "the style and subject-matter were, in their opinion, not such as should proceed from the mistress of one of their schools," but at the same time, they asked Elliott to form the school section and to have "the Indian householders appoint Trustees." ${ }^{75}$ It was around this time, the exact date of which is unknown, that Powless resigned her position.

A few months later, Elliott wrote back to the NEC, insulting Powless's experience as a teacher and explaining her resignation:

Mrs. Powless is of the Mohawk Tribe, and was appointed by the Reverend Mr. Nelles as teacher with my concurrence, not because she was as competent as we could wish, but chiefly on account of her being able to converse with the Indian children in their own language, as most of them have but little knowledge of English. In the course of last summer some of the Indians complained to me, and I believe not without reason, of her irregular attendance to her duties as teacher, and after a few months' notice, her services were discontinued at the end of December last. Mr. Isaiah Joseph an Indian youth who was educated at the Mohawk Institution was appointed as teacher in her stead. Her son, Mr. George Powless... is now the teacher of the New England Company's school No 9 instead of Isaiah Joseph. Both these Indian youths we consider suitable for the situation of schoolmasters, alike for their acquirements, acquaintance with the Indian dialects, and their exemplary conduct. ${ }^{76}$

It seems as though Powless left the school at least in part over a conflict with the NEC in the management of the school. It is difficult to know if Elliott's comments about 
her absences from school were based in fact or spurred by anger over her direct communication with his superiors. It is possible that she was absent from her work as a teacher; women tended to be the caregivers in their families, and she may have been caring for ill family members or ill herself. In 1871, her husband was no longer living with the family, and her widowed, aging mother, her son George, and a man who would later become her husband, William Loft, also resided with the family. Also living in the home was a one-year-old child named Minnia Washburn; her relation to the family is unclear. ${ }^{77}$ One wonders if care for her mother, or this child, was also connected to her absence the previous year. It is impossible to know how family responsibilities shaped Powless's career, but it seems clear that women faced additional barriers related to their gender.

When Elizabeth Martin Powless's teaching career ended, we are left with little evidence of what her life consisted. By 1901, she had moved with her second husband William Loft back to Tyendinaga. It is very possible that Elizabeth continued in her teaching career in some way after her resignation, but she does not show up teaching at Grand River again or at Tyendinaga. One point of interest is that both Elizabeth Martin Powless and Jemima Loft Beaver were married women who taught. The nonIndigenous women who appear on the salary lists in reserve schools (and there are a few) were generally unmarried. There was not much discussion about their marital status by the NEC or the Department of Indian Affairs. Early in the twentieth century, there was a policy shift or a change in convention, and female teachers began to resign upon marriage. This was the case in the first few decades of the twentieth century at these same schools. ${ }^{78}$

\section{Conclusion}

Throughout the nineteenth century, the "feminization of teaching" shaped public schools across Canada. According to Alison Prentice and Marjorie Theobald, school systems saw "the gradual increase in the numbers and proportions of women teaching... along with... low status and pay."79 While the Department of Indian Affairs (and the NEC) did not track the ethnicity of the teachers they hired, genealogical and local history methodologies - microbiography — demonstrates that a similar movement was afoot in on-reserve day schools, with both Indigenous and non-Indigenous women moving into these classrooms. These methodologies help reveal the Indigenous women who became teachers in schools in their own communities and elsewhere. ${ }^{80}$

The Kanyen'kehá:ka women in this article are just four of many Indigenous women who actively engaged in the colonial education system. Despite their efforts and intentions, they faced numerous barriers to participation, including material barriers and gendered challenges that made it difficult, and sometimes impossible, to teach. Despite these constraints, Catherine Loft and her cousins Jemima Beaver, Lydia Hill, and Elizabeth Powless persisted and forged a path in order to create new "ways of being" in a colonial world.

These women worked within a context in which, for numerous reasons, both practical and financial, NEC missionaries on the ground in these communities preferred 
Indigenous teachers. They were concerned with converting and educating as many people as possible and recognized that having a teacher who could communicate with the students from within their own language and culture was an effective tactic. Importantly, though, these missionaries favoured male teachers. While both male and female students were selected and groomed to further their education by becoming teachers, men appear in the missionary reports most frequently and usually in a more positive light than their female counterparts.

Some male Kanyen'kehá:ka leaders seemingly felt the same way. That Elizabeth Martin Powless and Jemima Loft travelled from Tyendinaga to Grand River suggests that they believed there were opportunities to teach in one of the numerous schools at Grand River that their cousin's experience at Tyendinaga demonstrated were not available at home. Making this move built on a tradition of work-related mobility that was relatively common for the Haudenosaunee, although it was less so for women. ${ }^{81}$ The stories of these women's efforts to participate in the new missionary education system and the varying responses from the Department of Indian Affairs, the missionaries, and the male chiefs and councilors tells us something about how women worked to create opportunities for themselves and the challenges they faced.

It is significant that the first female teachers in these two communities were all related and descended from some of the Six Nations' early political leaders. It suggests that perhaps these female descendants shared the leadership qualities shown by the men in their family, such as Isaac Hill, John Deserontyon, and Joseph Brant. Women teaching children was not a new concept, but becoming certified to teach by colonial governments and being hired in missionary day schools certainly was. Further research must be done to flesh out the histories of Kanyen'kehá:ka women's work in education, but these life stories from the mid-nineteenth century suggest that some women were keen to teach in day schools, and undoubtedly they played important roles in the education of Haudenosaunee youth. ${ }^{82}$

\section{Notes}

*The views expressed here are those of the author alone, and do not represent the views of the Ontario Ministry of Indigenous Relations and Reconciliation or the Government of Ontario. Research for this article was funded by the Social Sciences and Humanities Research Council (SSHRC).

1 A note on terminology: in this article, I have chosen to use the term "Kanyen'kehá:ka" for the people that some might know better as the Mohawk. The term means "the People of the Flint" in the Mohawk language. While Mohawk is more familiar to most people from outside of the community, many Indigenous communities and peoples are working to revitalize their languages and using the name that people called and call themselves, rather than a name created and used by Dutch, French, and British colonists. I have chosen to use the spelling "Kanyen'kehá:ka" rather than the spelling "Kanien'kehá:ka," because the spelling with the " $y$ " is more common at Grand River, where more of this paper takes place, while the "i" version tends to be more commonly used in Tyendinaga. I use the term "Kanyen'kehá" to refer to the language that some might know better as Mohawk. Thank you to Tehakanere, a language teacher at Six Nations of the Grand River, for his help with the spellings of the Kanyen'kehá language. 
2 Keith Jamieson, History of Six Nations Education (Brantford: Woodland Indian Cultural Educational Centre, 1987), 3.

3 Women and men were considered equally valuable to the community, and the gendered division of labour meant that women cared for the home community and were responsible for horticulture and the raising of children. Women also had a role in political matters: clan mothers were responsible for selecting and deposing chiefs. Because they raised and educated the children until a certain age, women could anticipate which boys would make strong leaders. Learning took place during everyday life. It was not separated from the experience of day-to-day activities, and women were responsible for those activities within the village. Co-operation, competence, co-existence, and individuality were the basis of Haudenosaunee children's education. Once children were seen to be capable, they were taught gender-appropriate skills by both men and women. See Judith K. Brown, "Economic Organization and the Position of Women among the Iroquois," Ethnohistory 17, no. 3 (1970): 151-67; Nancy Shoemaker, "The Rise or Fall of Iroquois Women," Journal of Women's History 2, no. 3 (1991): 39-40; Elizabeth Tooker, "Women in Iroquois Society," in Extending the Rafters: Interdisciplinary Approaches to Iroquoian Studies, ed. Jack Campisi (Albany: State University of New York Press, 1984): 109-23.

4 On residential schools, see two volumes from the Truth and Reconciliation Commission of Canada's final report: Truth and Reconciliation Commission of Canada, Canada's Residential Schools: The History, Part 1: Origins to 1939 and Canada's Residential Schools: The History, Part 2: 1939 to 2000 (Montreal and Kingston: McGill-Queen's University Press, 2015). Also see J. R. Miller, Shingwauks Vision: A History of Native Residential Schools (Toronto: University of Toronto Press, 1996), and John S. Milloy, A National Crime: The Canadian Government and the Residential School System, 1879-1896 (Winnipeg: University of Manitoba Press, 1999).

5 This article is part of my larger project on Indigenous teachers in nineteenth-century southern Ontario. The scholarship on reserve day schools in different places across Canada sometimes includes a discussion of Indigenous teachers, either briefly or in depth: Eileen Antone, "The Educational History of the Onyote'a:ka Nation of the Thames," Ontario History 85 (December 1993): 309-20; Ken Coates, "A Very Imperfect Means of Education: Indian Day Schools in the Yukon Territory," in Indian Education in Canada, Vol. 1: The Legacy, ed. Jean Barman, Yvonne Hébert, and Don McCaskill (Vancouver: UBC Press, 1986), 132-149; Susan Elaine Dueck, "Methodist Indian Day Schools and Indian Communities in Northern Manitoba, 1890-1925," Manitoba History 30 (1995): 2-16; W. D. Hamilton, Federal Indian Day Schools in the Maritimes (Fredericton: University of New Brunswick Press, 1986); Brittany Luby and Kathryn Labelle, "Cooperative Education at the Day School on Dalles 38C Indian Reserve, 1890-1910," Ontario History 107, 1 (Spring 2015): 88-110; T. Fleming, L. Smith, and H. Raptis, "An Accidental Teacher: Anthony Walsh and the Aboriginal Day Schools at Six Mile Creek and Inkameep, British Columbia, 1929-1942," Historical Studies in Education 19, 1 (Spring 2007): 1-24; Hope MacLean, "A Positive Experiment in Aboriginal Education: The Methodist Ojibwa Day Schools in Upper Canada, 1824-1833," Canadian Journal of Native Studies 22, 1 (2002): 23-63; Helen Raptis et al., What We Learned: Two Generations Reflect on Tsimshian Education and the Day Schools (Vancouver: UBC Press, 2016); Alison Norman, "True to my Own Noble Race': Six Nations Women Teachers at Grand River in the Early Twentieth Century," Ontario History 107, no. 1 (Spring 2015): 5-34. Martha Walls, " ' $t$ the teacher that cannot underst and their language should not be allowed': Colonialism, Resistance, and Female Mi'kmaw Teachers in New Brunswick Day Schools, 1900-1923," Journal of the Canadian Historical Association 22, 1 (2011): 35-68. 
6 Ronald Hoffman et al., Through a Glass Darkly: Reflections on Personal Identity in Early America (Chapel Hill, NC: Published for the Omohundro Institute of Early American History \& Culture, Williamsburg, Virginia, University of North Carolina Press, 1997), viii.

7 See Jennifer S. H. Brown and Elizabeth Vibert, eds., Reading Beyond Words: Contexts for Native History, 2nd edition (Toronto: University of Toronto Press, 2003).

8 Charles Hamori-Torok, "The Iroquois of Akwesasne (St. Regis), Mohawks of the Bay of Quinte (Tyendinaga), Onmpany ota'a:ka (the Oneida of the Thames), and Wahta Mohawk (Gibson), 1750-1945," 258-272, and Charles M. Johnston, "The Six Nations in the Grand River Valley, 1784-1847," 167-181, both in Aboriginal Ontario: Historical Perspectives on the First Nations, ed. Edward S. Rogers and Donald B. Smith (Toronto: Dundurn Press, 1994).

9 Mohawks of the Bay of Quinte, "Leaving Mohawk Valley: Stories from the Draper Manuscripts," accessed March 10, 2014, http://www.mbq-tmt.org/assets/Nation\%20 Building/Research/LeavingMohawk Valley-AmysEdit.pdf.

10 Frederick Reville, The History of the County of Brant (Brantford: Hurley Print Co., 1920), 37.

11 See Elizabeth Elbourne's recent article on how Christianity and Anglicanism were a means for Haudenosaunee elites to access the power of military and fur trade elites in Upper Canada. Elizabeth Elbourne, "Managing Alliance, Negotiating Christianity: Haudenosaunee Uses of Anglicanism in Northeastern North America, 1760s-1830s," in Mixed Blessings: Indigenous Encounters with Christianity in Canada, ed. Tolly Bradford and Chelsea Horton (Vancouver: UBC Press, 2016), 38-60. Thomas Peace also describes this earlier historical context in his article in this issue.

12 "The Anglican Parish of Tyendinaga - History," accessed March 10, 2014, http://www. parishoftyendinaga.org/history.htm.

13 Halimand to De Peyster (November 1784), quoted in Charles M. Johnston, The Valley of the Six Nations: A Collection of Documents in the Indian Lands of the Grand River (Toronto: Champlain Society for the Government of Ontario, University of Toronto Press, 1964), 52.

14 Carl F. Klinck, "Norton, John (Teyoninhokarawen)," Dictionary of Canadian Biography, accessed 30 March 2016, http://www.biographi.ca/en/bio/norton_john_6E.html. As Thomas Peace discusses in his article in this issue, Norton succeeded Louis Vincent Sawatanen, a Wendat teacher who moved to the Bay of Quinte with the Kanien'kehá:ka in 1784 .

15 Douglas Leighton, "Claus, Christian Daniel," Dictionary of Canadian Biography, accessed November 3, 2016, http://www.biographi.ca/en/bio/claus_christian_ daniel_4E.html.

16 The quotation comes from the title page of A Primer for the Use of the Mohawk Children/ Waerighwaghsawe Iksaongoenwa. London, England: C. Buckton, 1786. From Johnston, The Valley of the Six Nations, Plate 1.

17 Elbourne, "Managing Alliance, Negotiating Christianity."

18 W. Barry Hill, The Chapel's Place in Six Nations History, 1710-2016 (Brantford, ON: n.p., 2016).

19 Sally Weaver, "The Iroquois: The Grand River Reserve in the Late Nineteenth and Early Twentieth Centuries, 1875-1945," in Aboriginal Ontario: Historical Perspectives on the First Nations, ed. Edward S. Rogers and Donald B. Smith (Toronto: Dundurn Press, 1994), 252.

20 Ibid., 218-19.

21 Arthur C. Parker, The Code of Handsome Lake, the Seneca Prophet (Brantford: Iroqrafts, 1990). 
22 At one point, an apparently inexperienced Indigenous man was hired to teach, "for want of a white teacher," but was soon dismissed according to missionary Robert Lugger, and the school ceased to function for a period. Johnston, The Valley of the Six Nations, lxxxv.

23 Sir John Winnifrith, Robert Murray Collins, and Gerald Anthony Charrington, The New England Company, 1870-1992: A Charity for the Propagation of the Gospel in New England and the Parts Adjacent to America (Colchester, Essex: New England Company, 1993), 11.

24 Ibid., 15. Four or five teachers were employed at Grand River in these years, generally non-Indigenous men and women.

25 Truth and Reconciliation Commission of Canada, Canada's Residential Schools: The History, Part 1, 66. Robert Lugger was the New England Company missionary at Grand River (at what was called the Tuscarora Station) until 1837 when Abram Nelles became the senior missionary at Grand River. Nelles served as rector at the Mohawk church and principal of the Mohawk Institute for thirty-five years, and was given a Mohawk name, Shadekareenhes, meaning "two trees of equal height." After his retirement, Adam Elliott became missionary at Grand River. Douglas Leighton, "Nelles, Abram," in Dictionary of Canadian Biography, accessed April 11, 2016, http://www.biographi.ca/en/bio/nelles_ abram_11E.html. For more on the food served at the Mohawk Institute, see Alison Norman, "'Our Strength Comes from the Land': The Hybrid Culinary Traditions of the Six Nations of Grand River," Cuizine: The Journal of Canadian Food Cultures (Spring 2015), http://www.erudit.org/revue/cuizine/2015/v6/n2/1033506ar.html.

26 There are parallels here with Sean Carleton's article in this issue. His work suggests that in mid-nineteenth-century British Columbia, the colonial state worked to support missionary schools as a financially expedient way to check Indigenous peoples' power.

27 Margaret Connell Szasz, Indian Education in the American Colonies, 1607-1783 (Lincoln, NE: University of Nebraska Press, 2007), 104-106.

28 Elbourne, "Managing Alliance, Negotiating Christianity," 48-9. For more on this eighteenth-century context see Thomas Peace's article in this issue.

29 Society for the Propagation of the Gospel in New England, Report by a Committee of the Corporation Commonly called the New England Company, of their Proceedings for the Civilization and Conversion of Indians, Blacks, and Pagans, in the British Colonies in America and the West Indies, since the Last Report in 1832 (London: J. Masters, 1840), 219-220.

30 Ibid., 87.

31 Society for the Propagation of the Gospel in New England, Report by a Committee of the Corporation Commonly called the New England Company, of their Proceedings for the Civilization and Conversion of Indians, Blacks, and Pagans, in the British Colonies in America and the West Indies since the Last Report in 1840 (London: J. P. Gibson, 1846), 45.

32 February 9, 1859 Report, Nelles, in Report by a Committee of the Corporation Commonly called the New England Company, of their Proceedings for the Civilization and Conversion of Indians, Blacks, and Pagans, in the British Colonies in America and the West Indies since the Last Report in 1840 (London: J. P. Gibson, 1859), 2-3.

33 "The Past and Present Condition of the Six Nations, 1842," in Johnston, The Valley of the Six Nations, 310.

34 "Indians at Tyendinaga to the bishop of Toronto," September 7, 1843; T. G. Anderson, Manitowaning, to Col. S. P. Jarvis, Kingston, March 4, 1843, Archives of Ontario, Strachan Papers. See also Linda Tschanz, Native Languages and Government Policy, Native Language Series, no. 2 (London: University of Western Ontario, 1980), 5.

35 Company for the Propagation of the Gospel in New England and the Parts Adjacent in America, History of the New England Company: From its Incorporation, in the Seventeenth 
Century, to the Present Time: Including a Detailed Report of the Company's Proceedings for the Civilization and Conversion of Indians, Blacks, and Pagans in the Dominion of Canada, British Columbia, the West Indies and S. Africa, During the Two Years 18691870 (London: Taylor, 1871), 128.

36 "Report of the Hon. A. E. Botsford, Commissioner of the Company for the Propagation of the Gospel in New England and the Parts Adjacent in America, Appointed by a Commission under the seal of the Company, dated the 18th day of June, 1870," in History of the New England Company: From its Incorporation, in the Seventeenth Century, to the Present Time, 325-6.

37 July 12, 1860 report, O'Meara, in Report by a Committee of the Corporation Commonly Called the New England Company, of their Proceedings for the Civilization and Conversion of Indians, Blacks, and Pagans, in the British Colonies in America, and the West Indies (London: 1860).

38 Elizabeth Graham, The Mush Hole: Life at Two Indian Residential Schools (Waterloo: Heffle Publishing, 1997), 64.

39 Six Years' Summary of the Proceedings of the New England Company for the Civilization and Conversion of Indians, Blacks, and Pagans in the Dominion of Canada and the West Indies, 1873-1878 (London: Gilbert and Rivington, 1879), 136.

40 Jamieson, Echoes of the Past, 12. In the 1885 Kelly report by the Brant County School Inspector, the school was referred to as the "Mohawk Institution and Indian Normal School." Graham, The Mush Hole, 84.

41 Russell T. Ferrier, "History of the Mohawk Institute, Successful Graduates," Library and Archives Canada, RG10, Vol. 6200, File 466-1, Part 2.

42 Company for the Propagation of the Gospel in New England and the Parts Adjacent in America, Report of the Proceedings of the New England Company: For the Civilization and Conversion of Indians, Blacks, and Pagans in the Dominion of Canada, South Africa, and the West Indies, during the Two Years, 1871-1872 (London: Taylor, 1874), 123.

43 See Heather Howard for more on Six Nations teacher candidates in Toronto in the early twentieth century: Heather Howard, "Dreamcatchers in the City: An Ethnohistory of Social Action, Gender and Class in Native Community Production in Toronto" (PhD diss., University of Toronto, 2005).

44 Alison Norman, “'An Excellent Young Indian': Isaac Bearfoot and the Education of the Six Nations of Grand River" (paper presented at The House that Isaac Built: The Architecture of Cultures and Identities in Canada, Huron University College, London, Ontario, 13-15 May 2013). His name is spelled both Barefoot and Bearfoot, but in his own writings, he used the Bearfoot spelling.

45 Teachers were nominated by the band and approved by the department.

46 Alan Taylor, The Divided Ground: Indians, Settlers, and the Northern Borderland of the American Revolution (New York: Alfred A. Knopf, 2006), 124.

47 For more on this family see Mohawks of the Bay of Quinte, "Leaving Mohawk Valley: Stories from the Draper Manuscripts," http://www.mbq-tmt.org/assets/Nation\%20 Building/ Research/LeavingMohawk Valley-AmysEdit.pdf.

48 William Bartlett to the Mohawk councilors, January 14, 1860, Library and Archives Canada, RG10, Vol. 544, Reel C-13358, 443-444.

49 Ibid.

50 Rev. S. A. Anderson to William Bartlett, January 17, 1860, Library and Archives Canada, RG10, Vol. 414, Reel C-9618, 310-312.

51 Ibid., 311.

52 William Bartlett to R. T. Pennefather, superintendent-general of Indian Affairs, February 15, 1860, Library and Archives Canada, RG10, Volume 544, 471-472.

53 Rev. S. A. Anderson to William Bartlett, January 17, 1860, Library and Archives Canada, RG10, Vol. 414, Reel C-9618, 312. 
54 William Bartlett to unknown, July 9, 1860, Library and Archives Canada, RG10, Vol. 545, Reel C-13, 358, 82.

55 Rev. S. A. Anderson to unknown, January 30, 1860, Library and Archives Canada, RG10, Vol. 414, Reel C-9618, 317.

56 "Women Pioneers \& Trailblazers of the Mohawks of the Bay of Quinte. Catherine Loft: First Board Certified Female Teacher," http://www.mbq-tmt.org/assets/Nation\%20 Building/Research/FebruaryNewsletter-CatherineLoft.pdf.

57 Beaver's first name is listed as Jemima or Yagoweia, depending on the source. She was the daughter of Henry Loft and a woman named Jemima, both born in Canajoharie, New York, who immigrated to the Bay of Quinte area after the revolution. Interestingly, Henry's brother was John Loft, father of Lydia Loft Martin, mother of Elizabeth Powless, the other female teacher at Grand River I discuss in this paper. This makes teachers Mrs. Beaver and Mrs. Powless first cousins once removed. Jemima’s (or Yagoweia's) nephew was Frederick O. Loft. Loft family tree, Tammy Martin, Ohsweken Genealogy Society.

58 George Beaver, Iroquois Fires: The Six Nations Lyrics and Lore of Dawendine (Bernice Loft Winslow) (Newcastle, ON: Penumbra Press, 1995), 13. Henry may have died before the family left for Canada. One source suggests that they had printed more than four thousand copies of a simple religious book, in Kanien'kehá, and had distributed them between 1850 and 1852. A Memorial of Sa-sa-na, the Mohawk Maiden, who Perished in the Rail Road Disaster at Deposit, N.Y., February 18, 1852 (Hamilton: Waldron and Baker, Printers, 1852), 8. George Loft went on to work as the interpreter and catechist at the Cayuga church in the Tuscarora missionary station of the New England Company, where the Rev. Albert Anthony, an Indigenous man and former teacher, was the missionary. Six Years' Summary of the Proceedings of the New England Company for the Civilization and Conversion of Indians, Blacks, and Pagans in the Dominion of Canada and the West Indies, 1873-1878, x.

59 Susanna Moodie, Life in the Clearings versus the Bush (Toronto: McClelland \& Stewart, 1989), 178.

60 Susannah was killed in a train accident in 1852, and her obituary was published in the Owego Gazette, February 26, 1852. From A Memorial of Sa-sa-na, the Mohawk Maiden.

61 Ibid., 8.

62 Company for the Propagation of the Gospel in New England, Report of the Proceedings of the New England Company, 277.

63 Quoted in Abate Wori Abate, "Iroquois Control of Iroquois Education: A Case Study of the Iroquois of the Grand River Valley in Ontario, Canada" (PhD diss., University of Toronto, 1984), 142.

64 Lydia’s father was the grandson of Captain Isaac Hill and her mother was a granddaughter of both Joseph Brant and Captain John Deserontyon, the two most important Mohawk leaders of the period. Of the four women profiled in this paper, Lydia is the only woman who remained unmarried, and she is the only woman of the four to have an "occupation" listed as "schoolteacher" in the Canadian census of 1871. 1871 Census of Canada, Census Place: Tyendinaga, Hastings East, Ontario; Roll: C-9992; 40; Family No. 151.

65 Company for the Propagation of the Gospel in New England, Report of the Proceedings of the New England Company, 396.

66 Census of Canada, 1911. Census Place: 38-Tyendinaga Township, Hastings East, Ontario, p. 9, Family No. 88.

67 "Miss Lydia Hill," July 29, 1927. Brantford Expositor, 6. A search of passenger ship lists has proved inconclusive.

68 Canada, Annual Report of the Department of Indian Affairs, 1875, 87. 
69 Return F, Statement of the condition of the various Indian Schools within the Dominion, for the year ended 30th June, 1875," Annual Report of the Department of the Interior for the year ended 30th June, 1875. Printed by Order of Parliament, Ottawa, 1876.

70 Miss Hartley (who was likely non-Indigenous), Miss Martin (likely Haudenosaunee), and Mrs. Beaver are all listed as earning \$160. "The Indian Affairs, Province of Canada. Report of the half-year ended 30th June, 1864,” 24.

71 Portrait of Mrs. Powless, or Dayo-ra-co-sa (Sun in Water). National Anthropological Archives, Smithsonian Institution, NAA INV 00783600.

72 She had notable Haudenosaunee ancestors. Lydia's maternal grandfather was Captain Isaac Hill and her paternal grandmother was Catherine Rolleston, a German girl who was taken captive by the Mohawk in Pennsylvania, adopted, and who married George Onhyeateh Martin. Other family connections include her cousin, Chief George H. M. Johnson, father of poet and performer Pauline Johnson, and her brother, Peter Martin, better known as Dr. Oronhyatekha. See a family tree in Keith Jamieson and Michelle A. Hamilton, Dr. Oronhyatekha: Security, Justice, Equality (Toronto: Dundurn Press, 2016), 16.

73 The History of the Country of Brant (Toronto: Warners, Beer and Co, 1883), 688.

74 Department of Indian Affairs records suggest that she was teaching by 1864, and taught throughout the 1860s at the No. 6 School. Department of Indian Affairs, Province of Canada, "Report of the Half-year Ended 30th June, 1864," 24. New England Company records in the early 1870 s suggest that she had long taught school on the site where No. 4 was located.

75 Company for the Propagation of the Gospel in New England, Report of the Proceedings of the New England Company, 1874, 166-7.

76 Ibid.

77 Canada Census, 1871, database, FamilySearch, https://familysearch.org/ ark:/61903/1:1:M43K-NFT : 13 November 2014), Minnia Washburn in the household of Elizabeth Powless, Tuscarora (Indian Reserve), South Brant, Ontario, Canada; citing p. 54, line 5; Library and Archives Canada, Film number C-9915, Public Archives, Ottawa, Ontario; FHL microfilm 4,396,290.

78 Norman, " "True to my own noble race." "

79 Alison Prentice and Marjorie R. Theobald, "The Historiography of Women Teachers: A Retrospect," in Women Who Taught: Perspectives on the History of Women and Teaching, ed. Alison Prentice and Marjorie R. Theobald (Toronto: University of Toronto Press, 1991), 5.

80 This is the first article of a larger project I am conducting on Indigenous teachers in day schools in $19^{\text {th }}$ century Ontario. It is clear that numerous Indigenous people taught in day schools, and some in residential schools; many of them were women. See also Felicity Jensz, "Trawling Indian Office Reports for Elusive References to Indigenous Teachers in Canada, 1867-1900" paper presented at The Changing Face of Missionary Education, July 9-10, 2014, Westfälische Wilhelms-Universität Münster, Germany.

81 Carl Benn, "Mohawks as Workers," in Mohawks on the Nile: Natives Among the Canadian Voyageurs in Egypt, 1884-85 (Toronto: Dundurn Press, 2009). For a later period see Robin Jarvis Brownlie, " 'Living the Same as the White People': Mohawk and Anishinabe Women's Labour in Southern Ontario, 1920-1940,” Labour/Le Travail 61 (Spring 2008): 41-68.

82 While the history of Haudenosaunee women's involvement in education between the 1870 s and the present needs further research, the strong presence of Haudenosaunee women in the field of education, and particularly language education, suggests a continuance of this tradition in new forms. See for instance the Tsi Tyonnheht Onkwawenna (Mohawk Immersion program at Kenhtè:ke (Tyendinaga)), with 
Konwanonhsiyohstha Callie Hill as executive director (see http://www.raisingthewords. $\mathrm{com} /$ ), and Konwanonhsiyohstha Callie Hill's research into language revitalization, "Kanyen'kéha: Awakening Community Consciousness" (M.Ed. diss., University of Victoria, 2015); and Six Nations Polytechnic at Grand River, a centre of excellence for Indigenous community-based learning with President/CEO Rebecca Jamieson. The school now offers a Bachelor of Arts degree in Ogwehoweh Languages (Mohawk or Cayuga) (see http://www.snpolytechnic.com/). 